\title{
Estimation of peak discharges of historical floods
}

\author{
J. Herget, T. Roggenkamp, and M. Krell \\ Department of Geography, University of Bonn, Bonn, Germany \\ Correspondence to: J. Herget (herget@giub.uni-bonn.de) \\ Received: 29 April 2014 - Published in Hydrol. Earth Syst. Sci. Discuss.: 23 May 2014 \\ Revised: 19 August 2014 - Accepted: 29 August 2014 - Published: 13 October 2014
}

\begin{abstract}
There is no doubt that the hazard assessment of future floods, especially under consideration of recent environmental change, can be significantly improved by the consideration of historic flood events. While flood frequency inventories on local, regional and even European scale have already been developed and published, the estimation of their magnitudes indicated by discharges is still challenging. Such data are required due to significant human impacts on river channels and floodplains, though historic flood levels cannot be related to recent ones or recent discharges. Based on experiences from single local key studies, we present the general outline of an approach to estimate the discharge of the previous flood based on handed-down flood level and topographic data. The model for one-dimensional steady flow is based on the empirical Manning equation for the mean flow velocity. Background and potential sources of information, acceptable simplifications and data transformation for each element of the model equation are explained and discussed. Preliminary experiences regarding the accuracy of $\pm 10 \%$ are documented, and potential approaches for the validation of individual estimations are given. A brief discussion of benefits and limitations, including a generalized statement on alternative approaches, concludes the review of the approach.
\end{abstract}

\section{Introduction}

Water level data from previous floods provide important information on potential magnitudes of contemporary floods. Furthermore, information on historic floods enables a comparison with recent floods to help in their classification. Recently, the European Union approved a flood risk estimation guideline that regulates by law the quantitative consideration of previous floods (EU, 2007). Previous floods can be divided into historic and palaeofloods. The distinc- tion of historic and palaeofloods is based on the duration of historic times with handed-down historic documents or descriptions while palaeoflood events took place in prehistoric times. Note that in several previous publications (e.g. Benito et al., 2010; Brázdil et al., 2006; House et al., 2002; Thorndycraft et al., 2005) the term "palaeoflood" is used even for recent flood events quantified by means of indirect methods due to missing gauging stations. According to the established used of the prefix "palaeo", based on the oldGreek origin palaios, meaning "old" (e.g. in palaeoclimatology or palaeohydrology), a stricter, only temporal differentiation seems more logical. Historic times with detailed flood descriptions last for about one or two centuries, e.g. in many parts of North America, up to several millennia in the old cultures of ancient Egypt or China (e.g. Bell, 1970; Pang, 1987; Herget, 2012). Consequently, the time of the transfer of historic times flood events to palaeofloods differs regionally. Typically, most historic floods can be dated exactly with high temporal, and partly also spatial, resolution, reaching levels of hydrograph reconstructions with a temporal resolution up to minutes based on historic photographs (Roggenkamp and Herget, 2014). Temporally, palaeoflood evidence based on sedimentary or geomorphological remnants (e.g. Baker et al., 1988; Herget, 2012; House et al., 2002) can only be estimated using relative chronologies or physically based dating techniques like radiocarbon or optical stimulated luminescence and give less exact dates, but might even reach annual resolution for the entire Holocene times if dendrochronological data are available from trees rings in flood plains or varves in lakes (e.g. St. George and Nielsen, 2002; Stoffel et al., 2010; Corella et al., 2014). Palaeofloods can be analysed back throughout Earth's geological history but decrease by number and resolution in pre-Pleistocene times based on the less significant sedimentary evidence (e.g. Herget, 2012; House et al., 2002), while also quantitatively reconstructed 


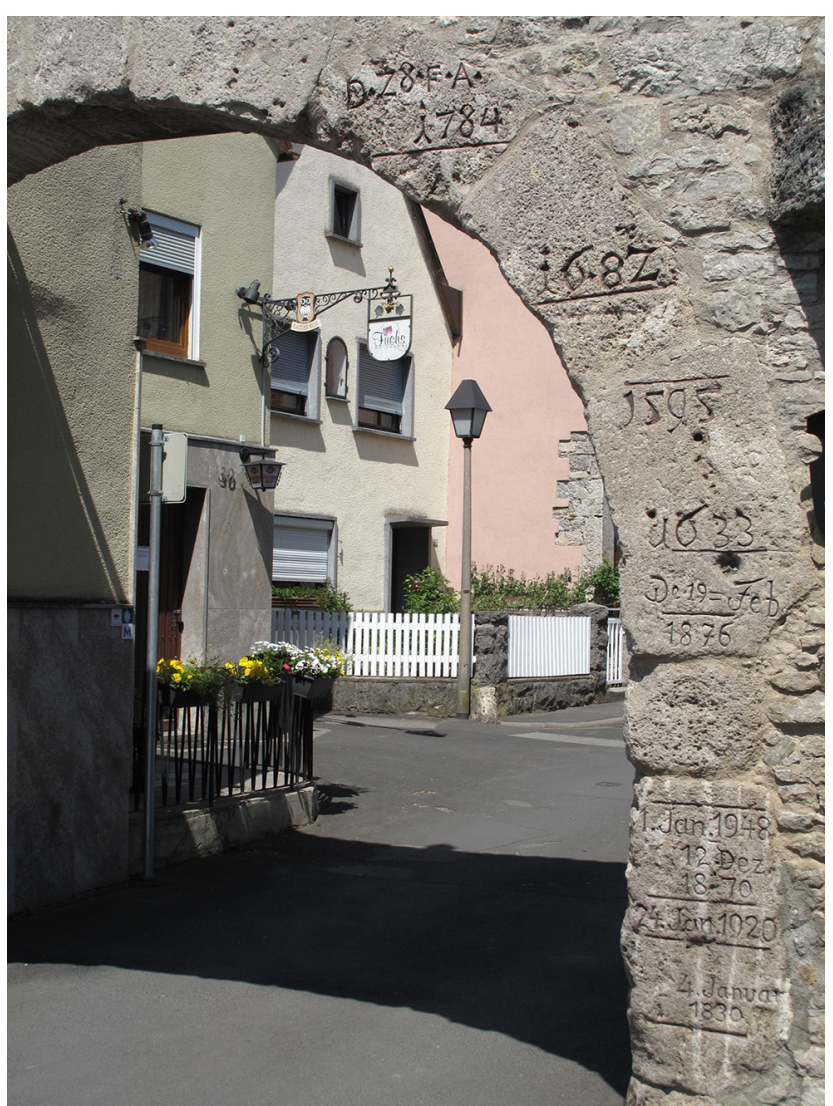

Figure 1. Flood marks of the River Main on the historic city fortification of Eibelstädt near Würzburg.

extraterrestrial flood and drainage events date back in astronomical timescales of billion of years (e.g. Burr et al., 2009). Here, we focus on historic floods in Europe, as their evidence and their relation to recent and near-future flood conditions are more obvious than for palaeofloods from geological times.

Historic flood levels can be found as markings on historic buildings (Fig. 1), identifying the maximum flood level, or in documentary sources (Deutsch et al., 2010). Usually, written descriptions compiled in source text compilations (e.g. Alexandre, 1987; Weikinn, 1958; www.tambora.org; Buisman and Van Engelen, 1995) are qualitative, such as "as a consequence of the flood, great damage was effected along the river at ...", but also semi-quantitative descriptions like "the water reached the doors of the church" are preserved. After careful interpretation and analysis, many of these descriptions can be used as flood level indicators for historic times, as is the case for rivers in Europe (e.g. Brázdil et al., 2012; Glaser et al., 2010; Herget, 2012), depending on the quality and quantity of the data. The approach of flood frequency analysis based on gauged flood events is well established, although the serious problem of statistical unsteadiness of data sets has to be dealt with (e.g. Benito and Thorndycraft, 2005; Kidson and Richards, 2005;
Savenije, 1995). By adding a significantly increased number of large flood events before the period of instrumental gauging, these data sets can be enhanced considerably (e.g. Witte et al., 1995; Benito and Thorndycraft, 2005). Direct utilization of these stage records in order to predict actual flood discharges is impossible due to frequent, mainly anthropogenic, modification of channels and nearby floodplains since historic times (e.g. Herget et al., 2005). For comparable discharges, modern water levels would reach a different elevation, in most cases probably higher, due to the decreased cross-section areas related to dykes, constructions and settlements on the floodplain. Therefore, the historic flood levels must first be transformed into historic peak discharges. These discharge values can then be used to estimate comparable modern-day flood levels by deriving peak discharges from historic events. In view of methodological problems, flood discharge estimations based on historic flood levels in urban areas are quite rare (e.g. Benito et al., 2003; Brázdil et al., 1999, 2005, 2006; Glaser et al., 2010; Thorndycraft et al., 2003), and some exceptions prove this rule (e.g. Elleder, 2010; Elleder et al., 2013; Herget and Meurs, 2010; Macdonald et al., 2006; Roggenkamp and Herget, 2014; Wetter et al., 2011).

Below, a review of a simple, suitable and more-or-less easily applicable approach is presented for estimating the discharge of previous floods based on preserved water level data. The method of the calculation itself with a focus on the determination respectively estimation of the parameters is given in detail below and commented based on experiences from previous applications of the approach in several local key studies. A discussion of limits and advantages in comparison with other approaches concludes this review.

\section{The method and parameter determination}

With the insertion of the empirical Manning equation for mean flow velocity $v$ (Chow, 1959) into the continuity equation describing discharge $Q$ as a product of cross-section area $A$ and flow velocity $v$, discharges for specified stages of historical flood events can be calculated as

$Q_{i}=A_{i} R_{i}^{2 / 3} S_{i}^{1 / 2} n_{i}^{-1}$,

with $Q_{i}$ the discharge $\left[\mathrm{m}^{3} \mathrm{~s}^{-1}\right], A_{i}$ the cross-section area $\left[\mathrm{m}^{2}\right]$ of the floodplain area for the specific flood level, $R_{i}$ the hydraulic radius $[\mathrm{m}]$ for the flood level determined as a quotient of the cross-section area $A_{i}\left[\mathrm{~m}^{2}\right]$ and the wetted perimeter $P_{i}[\mathrm{~m}], S_{i}$ the energy line slope $\left[\mathrm{m} \mathrm{m}^{-1}\right]$, and $n_{i}$ the hydraulic roughness coefficient [-] according to Manning.

For different stages of a flood event, most of the factors of the equation vary (see the following subchapters) and therefore have to be related to a specific stage, e.g. the maximum one of the peak discharge as handed down by most flood marks. Due to the empirical character of the Manning equation, Eq. (1) is not true by units (cf. Chow 1959 


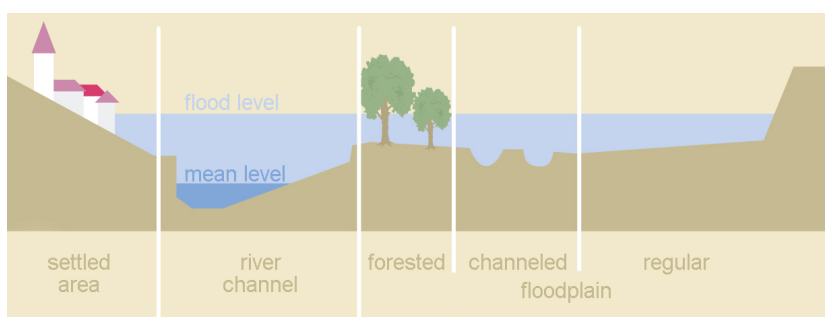

Figure 2. Scheme of homogenous units of floodplains with different hydraulic roughness characteristics (modified from Herget, 2012).

for details and discussion). As Eq. (1) determines the discharge related to a specific stage of a flood, a uniform onedimensional steady flow is modelled. Ice-jam-related floods (Beltaos, 2008, 2014) cannot be quantified by the approach due to the temporal blockage of the channel as a reason for the flood level instead of an increased discharge.

If one looks more closely, floodplains of river valleys consist of several units with significantly different hydraulic roughness caused by obstructions like buildings or vegetation, surface roughness as a result of minor landforms like floodplain channels, or hills and depressions in addition to different land use (Fig. 2). Generally speaking, the units of settled areas, the river channel, and the floodplain obviously provide different hydraulic roughness. Additionally, they developed and changed differently in historic times, and therefore they have to be considered individually. The floodplain can be further subdivided into open ground of agricultural use, flood plain channels eroded and incised by previous flood events, and floodplain forests with dense vegetation cover dominated by trees and bushes. Consequently, the discharge is calculated separately for individual homogenous units of the inundated cross-section area $A$ and subsequently simplified to a single value for the flood event. Each of the units has to be reconstructed for its appearance and hydraulic roughness at the point of time the historic flood event occurred. Uniform flow within each unit is assumed.

Within each of the units, the parameters of Eq. (1) are quantified according to the scheme illustrated in Fig. 3 and individually explained in detail below. In case significant uncertainties arise for the flood event itself - e.g. different water levels from different reliable and verified sources or missing information if the debris of a destroyed stone bridge filled and blocked the river channel during the flood event or not (cf. Herget et al., 2014, for details of these problems related to the July 1342 flood event) - different scenarios based on varying assumptions should be considered. Arguments for or against the plausibility of the individual scenarios can be based on the derived discharge calculations and their relation to discharge calculations at additional locations up- or downstream along the river for the same event.

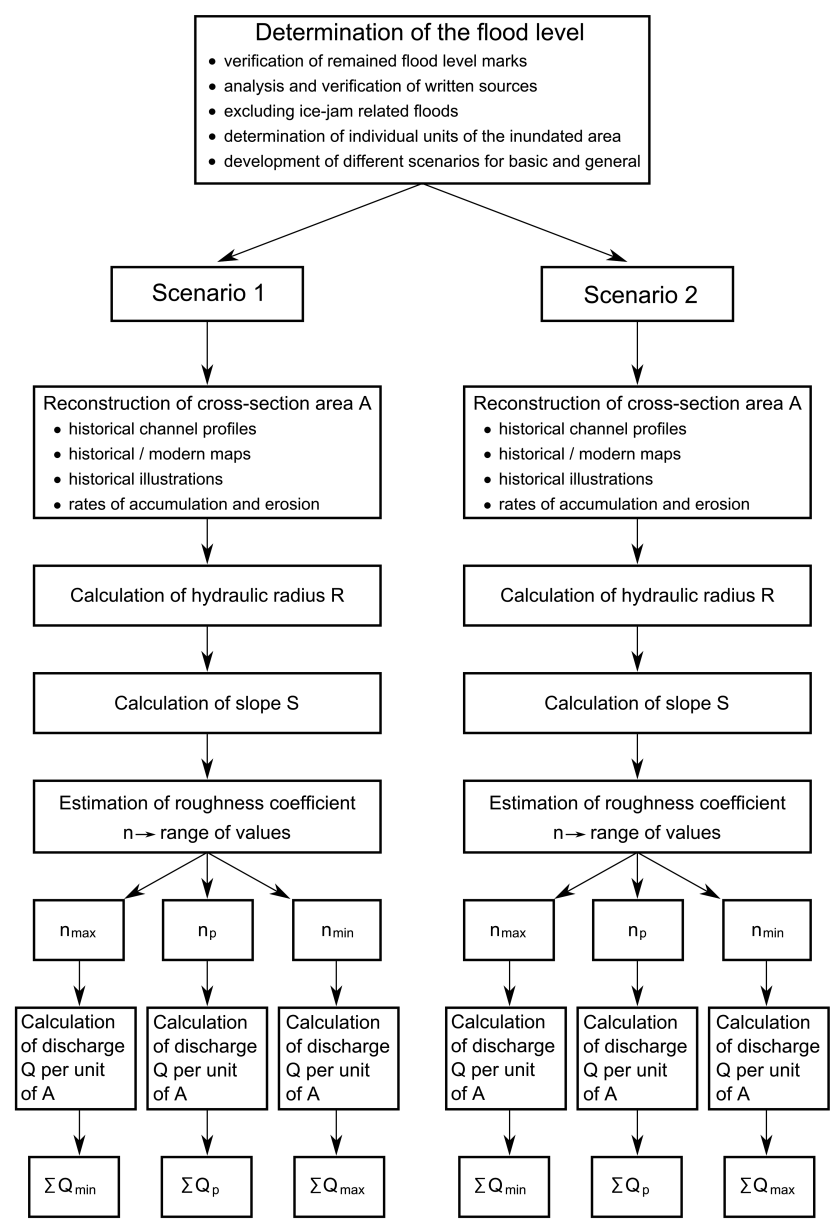

Figure 3. Scheme of discharge calculation and main aspects of parameter quantification.

\subsection{Cross-section area $A$}

As illustrated in Fig. 2, the level of the specific flood of interest dominates the magnitude of the cross-section area $A$. The reconstruction of the topography of the inundated floodplain area is based on data from historic maps, etchings and drawings. Typically, locations of historic importance with verified flood marks will have already experienced rather detailed investigation of their urban archaeology. Based on these illustrations and archaeological studies, any significant topographic change - including land use change on the floodplain and expansion of the settlement - can be backtracked qualitatively and partly even quantitatively by the thickness of time-specific sedimentary layers through time. For reference, modern large-scale topographic maps with detailed elevation data can be used and differences as a result of erosion or accumulation through time quantified along the profile of the cross-section area. Based on experiences it is recommended that all data be converted into metric units and related to metres above sea level, as local reference points (such as gauge datum), measurement units, and calibrations (such as map 
datum) were changed through historic times. The use of relative values like height above gauge datum might be a source of confusion.

According to elevation changes, the separated units of the inundated floodplain (Fig. 2) show different characteristics and require detailed investigations. For the areas of the settlement itself, a tendency towards accumulation can be observed. The background is the typical repeated rebuilding of historic settlements after destruction by fire, war or systematic modernization on top of the remnants and debris of the previous buildings. In particular, measures for the stabilization of shorelines at harbour areas in order to protect against minor floods result in significant accumulation. In Cologne, the anthropogenic embankment of the nearshore areas towards the River Rhine measures up to $10 \mathrm{~m}$ locally for the last 2000 years (Herget and Meurs, 2010) Due to anthropogenic measures, changes within the settled areas took place at certain points of time, while more-or-less continuous rates of aggradation or erosion can be observed in the neighbouring river channel and on the floodplain. Destructive single events, like the July 1342 flood, resulting from intensive erosive rainfall with local immense accumulations of colluvial deposits (Bork, 2014; Kiss, 2009; Zbinden, 2011) illustrate the complexity of the phenomenon. Nonetheless, for urban areas where the long-lasting handed-down flood level history is localized, the simplification of the trends mentioned above provides a framework for potential results of detailed local investigations.

As most large river channels are excavated to improve navigation and narrowed to provide space for additional settlements, the natural conditions are rarely preserved. Due to missing systematic investigations and measurements, data on natural river channel geometry from historic times are rare. Only occasionally have systematic bathymetric measurements been carried out and documented in detail and thus considered in detail for channel reconstructions (e.g. Elleder et al., 2013; Herget and Meurs, 2010). Frequently, reports and plans regarding how to improve river channel conditions in the historic near-future provide data about maximum values of natural channel depths, as the excavated channels will be deeper than the natural ones. If no historic maps or paintings exist that are more or less true to scale, the construction and lengths of bridges might support first estimations of historic channel widths (BGU, 2011). Based on the oldest data on channel geometry, previous conditions can be estimated by means of the extrapolation of handed-down geometry considering natural incision or aggradation rates. Theoretically, numerous aspects like change in trends as a result of tectonic movement, climatic change, or land use change resulting in variability of the hydrology and sediment budget might be expected to cause serious problems for such extrapolation. On the other hand, the time period back to the earliest historic flood events with sufficient data for a quantitative reconstruction in Europe dates back to late medieval times. Annual natural rates of incision of rivers of, for example, $1 \mathrm{~mm} \mathrm{a}^{-1}$ - which is a rather unrealistically high value considering differences in altitude of river terraces (Bridgland and Westaway, 2008; Schirmer, 1995) - would result in a difference of a few decimetres. As we are dealing with high-magnitude deep-water floods inundating flood plains with widths of several kilometres, depth variations of such dimensions in the relatively narrow river channel itself do not influence the dimension of entire cross-section area significantly (compare, for example, Elleder et al., 2013, or Herget and Meurs, 2010, with different observations on natural river channel trends in historic times). Note that this preliminary assessment should not be transferred arbitrarily to any river channel, as, globally speaking, more extreme trends such as more-or-less natural aggradations of $>10 \mathrm{~m}$ in just one century are also observable (Qingchao, 1989).

The width of the neighbouring floodplains in historic times might be considerably underestimated, as dykes allowed for the expansion of settlements and the installation of infrastructure (Schenk, 2001). For example, the width of the natural floodplain of the River Rhine at Cologne is about $9000 \mathrm{~m}$, while the recent distance between the dykes or rather higher terrace levels is down to $350 \mathrm{~m}$ (Herget and Meurs, 2010). The floodplains have the tendency to rise as a result of the deposition of suspension load during floods. The accumulation of the sediments might have reached significant thickness, but must be differentiated by age. Geological and soil maps or archaeological excavations provide suitable information about the age of the floodplain deposits. Like for the river channel incision, a closer look at elevation changes derived from extrapolated aggradation rates reveals a minor influence for broad floodplains in Europe. Local exceptions related to extreme events - such as the 1342 flood mentioned above, or the rise of the valley bottom of $3.9 \mathrm{~m}$ since about 1210 in the village of Grünsfeldhausen, located in a small valley $10 \mathrm{~km}$ southwest of Würzburg, indicated by the level of the entrance of the church below the surface (Hahn, 1992) - are again exceptions to the rule. On the other hand, these examples again illustrate the necessity of careful investigation for local studies.

\subsection{Hydraulic radius $R$}

The hydraulic radius is calculated as $R=A / P$, where $A$ is the cross-section area and $P$ is the wetted perimeter; it considers the shape of the cross-section area, as along the shores and the channel bottom, roughness elements decrease the mean flow velocity. Like the cross-section area, the wetted perimeter can be determined from modern topographic maps with consideration of the same properties of the features along the profile as discussed for the cross-section area. 


\subsection{Slope $S$}

Strictly speaking, the slope, $S$, is the slope of the energy line along the flow direction (Chow, 1959). It can be seen from closer inspection along river section of sufficient length that the slope of the water surface and the energy line are parallels, which significantly eases the quantification. Within the region of the cross-section profile, no significant backwater effects from narrow culverts at bridges or other obstructions like mills or weirs, including cliffs at the channel bottom, should influence the water level at the flood stage. If no significant obstacle has been introduced since the occurrence of the historic floods of interest, the recent slope of the water surface can be transferred, as incisions or aggradations occurred over a longer section, resulting in a parallel rise or lowering of the energy line. For a known slope $S$ and assurance that the water level was not influenced along the way, heights of flood level marks from other locations within the area of the study can be transferred to the cross-section profile. Note that their absolute height must be modified considering the value of the slope.

\subsection{Hydraulic roughness $n$}

The hydraulic roughness reducing the mean flow velocity is quantified by empirical values based on experiences and is available from tables and manuals (e.g. Arcement and Schneider, 1989; Barnes, 1967; Chow, 1959). Chow (1959, $101 \mathrm{pp}$.) analysed the elements affecting the hydraulic roughness and found the principal algebraic form of

$n=\left(n_{1}+n_{2}+n_{3}+n_{4}+n_{5}+n_{6}+n_{7}+n_{8}+n_{9}\right) m$,

where $n_{1}$ represents surface roughness, $n_{2}$ vegetation, $n_{3}$ channel irregularity, $n_{4}$ channel alignment, $n_{5}$ obstructions, $n_{6}$ silting and scouring, $n_{7}$ stage and discharge, $n_{8}$ sediment load (density of water), $n_{9}$ seasonal changes, and $m$ a correction factor for channel meandering.

Assuming that the sediment load did not reach concentrations of hydraulic influence like hyper-concentrated flow during the historic flood event of interest, and considering the steady flow conditions modelled, the summands $n_{6}-n_{9}$ do not require further consideration. Consequently, Eq. (2) is simplified to

$n=\left(n_{1}+n_{2}+n_{3}+n_{4}+n_{5}\right) m$.

These roughness elements are components reducing the mean one-dimensional flow velocity as result of turbulences. Surface roughness $n_{1}$ is caused by larger or smaller grain size of the sediments at the channel bottom up to minor submerged obstacles. The influence of vegetation $n_{2}$ obviously changes throughout the year and hence differs for the same floodplain by season. Channel irregularities $n_{3}$ are typically submerged bedforms such as local scour holes, sedimentary bars, or riffles and pool structures influencing the vertical component of the current above. The channel alignment $n_{4}$ is the similar horizontal effect generated by any deviation in the lateral shores from a straight line. Obstructions $n_{5}$ are large obstacles within the channel or floodplain, like trees or houses, that might reach from the bottom up to the surface of the flood level. Any deviation in the river channel or floodplain orientation from a straight line, such as a meander, generates secondary currents which reduce the main onedimensional flow velocity. Hence, the degree of the deviation from straight is proportional to a value of $m>1$, which increases the roughness and decreases the mean flow velocity.

From the references mentioned above, values for each component of Eq. (3) can be taken. The degree of the strength of the roughness characteristic varies and requires experiences with the estimation of the representative value. Therefore, in the source tables, data ranges with minimum, typical and maximum values for classified degrees of the development of each element are given. As it is already challenging to estimate a suitable roughness value for recent channels, the limited detailed information on historic channel conditions increases the uncertainty significantly. Consequently, the range of $n$ values is taken over into the final discharge calculation, resulting in minimum (for upper range roughness), maximum (for lower range roughness) and a plausibly balanced representative value for each roughness component (Fig. 3). The value of $n_{p}$ that has been balanced according to all available information is not necessarily the mean value between $n_{\min }$ and $n_{\max }$ but is frequently chosen so arbitrarily due to missing detailed information. For each unit of the cross-section profile, three roughness values of a range of $n_{\min }<n_{p}<n_{\max }$ are estimated to take into account the individual aspects of hydraulic roughness, consequently resulting in three discharge values that are finally summarized separately to the flood discharge of the entire cross-section.

Based on experiences from previous key studies, the different units of a cross section have specific roughness characteristics, which are briefly summarized below.

Flood water in inundated modern cities with relatively broad, straight roads is, compared with medieval towns, frequently standing and does not flow through town (e.g. Elleder et al., 2013; Herget and Meurs, 2010; Roggenkamp and Herget, 2014). Obviously the roughness exceeds a threshold and prevents the water from flowing as fast as on the open floodplain or within the river channel. Considering that most historic towns were fortified with a surrounding city wall and typically featured narrow winding alleys instead of the recent four-lane straight roads, this effect might have been even stronger. This phenomenon, indicated by a mirror effect visible on photographs of inundated areas, has significant consequences for discharge estimation, as the dense settled areas of the floodplain might be left out since the water there is standing and not moving. Note that this important observation requires further confirmation but so far provides significant simplification, as high-resolution topographic data from within medieval cities would be hard to determine. 
Table 1. Comparison chart for estimated and measured peak discharges of selected flood events (partly from Meurs, 2006, and Roggenkamp, 2012).

\begin{tabular}{|c|c|c|c|c|c|c|}
\hline \multirow{2}{*}{ Flood event } & \multirow{2}{*}{ River/city } & \multicolumn{3}{|c|}{$\begin{array}{c}\text { Estimated peak } \\
\text { discharge }\left[\mathrm{m}^{3} \mathrm{~s}^{-1}\right]\end{array}$} & \multirow{2}{*}{$\frac{\begin{array}{r}\text { Gauge data } \\
{\left[\mathrm{m}^{3} \mathrm{~s}^{-1}\right]}\end{array}}{Q_{\text {gauge }}}$} & \multirow{2}{*}{$\begin{array}{r}\text { Difference } Q_{p} \\
\quad \text { to } Q_{\text {gauge }}\end{array}$} \\
\hline & & $Q_{\min }$ & $Q_{p}$ & $Q_{\max }$ & & \\
\hline November 1882 & Rhine/Andernach & 8970 & 9785 & 10762 & 10700 & $-9 \%$ \\
\hline November 1882 & Rhine/Düsseldorf & 7391 & 8648 & 10549 & 10400 & $-17 \%$ \\
\hline November 1882 & Rhine/Rees & 6047 & 7326 & 9422 & 10200 & $-28 \%$ \\
\hline January 1883 & Rhine/Mainz & 4455 & 5060 & 5860 & 6940 & $-27 \%$ \\
\hline January 1883 & Rhine/Andernach & 8317 & 9073 & 9980 & $<9530$ & $-5 \%$ \\
\hline January 1883 & Rhine/Düsseldorf & 6965 & 8142 & 9915 & 9710 & $-16 \%$ \\
\hline January 1883 & Rhine/Rees & 6200 & 7518 & 9676 & 10500 & $-28 \%$ \\
\hline April 1983 & Rhine/Cologne & 7800 & 9100 & 10200 & 9486 & $-4 \%$ \\
\hline May 1983 & Rhine/Cologne & 7950 & 9300 & 10400 & 9724 & $-4 \%$ \\
\hline March 1988 & Rhine/Cologne & 7950 & 9300 & 10400 & 9708 & $-4 \%$ \\
\hline December 1993 & Rhine/Cologne & 8750 & 10250 & 11450 & 10836 & $-5 \%$ \\
\hline January 1995 & Rhine/Cologne & 8900 & 10450 & 11650 & 10939 & $-4 \%$ \\
\hline January 2003 & Rhine/Cologne & 7650 & 8950 & 10000 & 9329 & $-4 \%$ \\
\hline May 1984 & Ahr/Altenahr & 148 & 182 & 232 & 192 & $-5 \%$ \\
\hline March 1988 & Ahr/Altenahr & 143 & 176 & 225 & 190 & $-7 \%$ \\
\hline
\end{tabular}

As the reconstruction of the geometry of historic river channels is already a challenge, an even more detailed determination of their roughness elements and the degree of their development appears rather unlikely. The uncertainty regarding the existence and dimensions of mobile bedforms such as gravel dunes or water plants illustrates the problem. On the other hand, the reconstruction of historic floods typically has to do with large-scale, high-magnitude events of considerable water depth. In particular, the significantly increased depth of flow in relation to mean flow conditions and its characteristic expansion of the entire floodplain obviously reduce the significance of the uncertainty regarding these relatively minor roughness elements.

Open floodplains near historic locations like cities or monasteries with localized flood level information have typically been used for agriculture. Even though knowledge on plants, techniques and methods used in historic agriculture is well developed, a high-resolution picture cannot be determined. The reason is that it is impossible to estimate, with regard to location, which kind of plant, of which size, and of which seasonal leaf development exactly was growing at the point of time of the flood occurrence. Based on the season the flood occurred, a more general picture of dense or, conversely, missing agricultural vegetation cover with characteristic roughness value ranges can be plausibly quantified. Parts of the floodplain might have remained forested, but there are uncertainties about species and densities, like for the areas of agricultural use as mentioned before. Barnes (1967) documented photographic evidence of the appearance of floodplain forests with measured roughness values that might ease estimations for historic environmental conditions, at least for a plausible magnitude of $n$ values. Even though the floodplain channels might still be delimitable in recent urban topography (e.g. http://www. hw-karten.de/koeln/ for the example of Cologne), their historic appearance is not documented. Within the agriculturally used floodplain, the incised and rather wet channels due to close groundwater contact were only disturbing agicultural activities and not worth further mention. From the recent topography, minimum values of these channels' dimensions are indicated by their steep lateral slopes grown over with bushes, and relatively dense vegetation cover (cf. Herget and Meurs, 2010). Consideration of expanded floodplains of such uncertain characteristics like those characterized above with spread roughness value ranges explains why the approach presented here will always result in flood discharge ranges and not distinct values, regardless of what future improvements to the approach will look like.

\subsection{Validation and plausibility check}

Validation of the estimated discharge data is possible by the application of the method on recent flood events and comparison of the estimation with gauge data. Table 1 presents mainly unpublished data based on flood reconstruction along the rivers Rhine and Ahr, a minor tributary upstream from Bonn. Note that no improvements to the flood discharge estimations were carried out by adaptation of $n$ values to narrow the differences with measured discharges.

Even though the comparisons documented in Table 1 are not representative, a tendency towards underestimation of flood discharge for $Q_{p}$ values is obvious. Typically, $Q_{p}$ estimations are up to $10 \%$ less than the related gauge data, while floods modelled in the low-level gentle slope regions 
of the Lower Rhine at Düsseldorf and Rees differ even more. Due to limited possibilities for gauge calibrations, even discharge measurements of recent floods with water levels very far beyond bankfull inundating a broad differently structured floodplain are less certain (e.g. Morgenschweis, 2011).

An additional approach for plausibility testing is the repeated reconstruction of flood discharges along rivers at different locations and checking of consistency, e.g. increasing discharge downstream of confluences with major tributaries or relation to reliable locations for the same event (e.g. Elleder et al., 2013).

\section{Conclusions}

Based on sufficient historic background data such as water level and previous topography, the approach is suitable for estimating the discharge of historic flood events with an accuracy of approximately $\pm 10 \%$. Application of the approach to recent floods and comparison with gauge data indicate a tendency towards underestimation of the discharge based on data available so far. Questionable data like contradictory handed-down flood level data/information and uncertainties about the influence of destroyed bridges probably filling the river channel (e.g. Herget et al., 2014) can be dealt with by modelling different scenarios and use of subsequent plausibility checks of the estimated discharge data with additional locations up- and downstream from the river. Additional sources of error are less significant than one might expect, as high water levels over broadly inundated floodplains compensate for less distinct values of the river channel morphology, the historic accumulation level of floodplain sediments or extrapolated incision and accumulation rates. Rather time-consuming is the research regarding historic data on river channel conditions, high-resolution historic topography, and data of annual incision or accumulation rates of the river channel and floodplain in historic times.

The model itself is rather basic, considering simplified current patterns of one-dimensional steady flow that are far below the real flow pattern of a passing-through flood wave. Two- or three-dimensional models for unsteady flow would obviously be more realistic, but usually cannot be fed with sufficient high-resolution input data based on evidence from historic times. Some exceptions (e.g. Bürger et al., 2006; Calanda et al., 2003) prove this rule and might be considered for scientific and methodological interest rather than applied flood hazard assessment. Note that an increase in model complexity does not automatically lead to an improved result, neither by spatial resolution nor accuracy, but is much more complicated to deal with (Carling et al., 2003).

Further improvement and development of the approach might occur as a result of dealing with flood flow currents passing through settled areas. High-resolution data on the detailed structure at the point of time of a specific flood event is as challenging as the flow itself. A possible perspective could be either high-resolution modelling or the estimation of hydraulic roughness $n$ values for settled areas.

Author contributions. T. Roggenkamp and M. Krell carried out local studies along the Rivers Ahr and Rhine (T. Roggenkamp) and Rhine and Main (M. Krell). J. Herget prepared the manuscript based on their material and previous own and other publications, and the manuscript that was ultimately submitted was checked by all coauthors.

Acknowledgements. The authors thank numerous colleagues for their support through provision of data and access to material for the key studies providing the background for this review paper. The investigations were kindly support by the German Research Foundation (DFG) (HE 3006/9-1).

Edited by: G. Blöschl

\section{References}

Alexandre, P.: Le climat en Europe au Moyen Age, École des hautes études en sciences socials, Paris, 1987.

Arcement, G. J. and Schneider, V. R.: Guide for selecting Manning's roughness coefficients for natural channels and flood plains. USGS Water Supply Paper 2339, United States Geological Survey, Denver, 1989.

Baker, V. R., Kochel, R. C., and Patton, P. C. (Eds.): Flood geomorphology, Wiley, New York, 1988.

Barnes, H. H.: Roughness characteristics of natural channels. USGS Water Supply Papers 1849, United States Geological Survey, Denver, 1967.

Bell, B.: The oldest records of the Nile floods, Geograph. J., 136, 569-573, 1970.

Beltaos, S.: Progress in study and management of river ice jams, Cold Reg. Sci. Tech., 51, 51, 2-19, 2008.

Beltaos, S.: Hydrodynamic properties of ice-jam release waves in the Mackenzie Delta, Canada, Cold Reg. Sci. Technol., 103, 91106, doi:10.1016/j.coldregions.2014.03.011, 2014

Benito, G. and Thorndycraft, V. R. (Eds.): Systematic, palaeoflood and historical data for the improvement of flood risk estimation - methodological guidelines, Centro de Ciencias Medioambientales, Madrid, 2005

Benito, G., Díez-Herrero, A., and de Villalta, M.: Magnitude and frequency of flooding in the Tagus river (Central Spain) over the last millennium, Clim. Change, 58, 171-192, 2003.

Benito, G., Rico, M., Sánchez-Moya, Y., Sopeña, A., Thorndycraft, V. R., and Barriendos, M.: The impact of late Holocene climatic variability and land use change on the flood hydrology of the Guadalentín River, southeast Spain, Global Planet. Change, 70, 53-63, 2010.

BGU: Bayerische Gesellschaft für Unterwasserarchäologie (Ed.): Archäologie der Brücken, Pustet, Regensburg, 2011 
Bork, H.-R.: Spuren in der Landschaft - extreme Witterungsereignisse während des Spätmittelalters und ihre Folgen, Deutsche Wasserhistorische Gesellschaft Schriften 22, 107-126, Siegburg, 2014.

Brázdil, R., Dobrovolný, P., Elleder, L., Kakos, V., Kotyza, O., Květoň, V., Macková, J., Müller, M., Štekl, J., Tolasz, R., and Valášek, H.: Historical and recent floods in the Czech Republic. Masaryk University/Czech Hydrometeorological Institut, Brno/Prague, 2005.

Brázdil, R., Glaser, R., Pfister, Ch., Dobrovolný, P., Antoine, J.-M., Barriendos, M., Camuffo, D., Deutsch, M., Enzi, S., Guidoboni, E., Kotyza, O., and Sanchez Rodrigo, F.: Flood events of selected European rivers in the sixteenth century, Clim. Change, 43, 239285, 1999.

Brázdil, R., Kundzewicz, Z. W., and Benito, G.: Historical hydrology for studying flood risk in Europe, Hydrolog. Sci. J., 51, 739764, 2006.

Brázdil, R., Kundzewicz, Z. W., Benito, G., Demarée, G., Macdonald, N., and Roald, L. A.: Historical floods in Europe in the past millennium, in: Changes in flood risk in Europe, edited by: Kundzewicz, Z. W., IAHS Special Publication 10, 121-166, Wallingford, 2012.

Bridgland, D. and Westway, R.: Preservaton patterns of Late Cenozoic fluvial deposits and their implications - results from IGCP 449, Quaternary Int., 189, 5-38, 2008.

Buisman, J. and van Engelen, A.: Duizend jaar weer wind en water in de Lage Landen, Van Wijnen, Franeker, 1995-2006 (five volumes).

Bürger, K., Dostal, P., Seidel, J., Imbery, F., Barriendos, M., Mayer, H., and Glaser, R.: Hydrometeorological reconstruction of the 1824 flood event in the Neckar River basin (southwest Germany), Hydrol. Sc. J., 51, 864-877, 2006.

Burr, D. M., Carling, P. A., and Baker, V. R. (Eds.): Megaflooding on Earth and Mars. Cambridge University Press, Cambridge, 2009.

Calanda, G., Calvani, L., and Mancini, P.: Simulation of the great flood of December 1870 in Rome, Water Maritim. Eng., 156, 305-312, 2003

Carling, P., Kidson, R., Cao, Z., and Herget, J.: Palaeohydraulics of extreme flood events - reality and myth, in:Palaeohydrology understanding global change, edited by: Gregory, K. J. and Benito, G., Wiley, Chichester, 325-336, 2003.

Chow, V. T.: Open channel hydraulics, McGraw-Hill, New York, 1959.

Corella, J. P., Benito, G., Rodriguez-Lloveras, X., Brauer, A., and Valero-Garcés, B. L.: Annually-resolved lake record of extreme hydro-meteorological events since AD 1347 in NE Iberian Peninsula, Quaternary Sc. Rev., 93, 77-90, 2014.

Deutsch, M., Glaser, R., Pörtge, K.-H., Börngen, M., Drescher, A., Martin, B., Riemann, D., and Schönbein, J.: Historische Hochwasserereignisse in Mitteleuropa - Quellenkunde, Interpretation und Auswertung, Geographische Rundschau 3, 18-24, 2010.

Elleder, L., Herget, J., Roggenkamp, T., and Nießen, A.: Historic floods in the city of Prague - reconstruction of peak discharges, Hydrol. Res., 44, 202-214, 2013.

Elleder, L.: Reconstruction of the 1784 flood hydrograph fort he Vlatava River in Prague, Czech Republic, Global Planet. Change, 70, 117-124, 2010.
EU: Richtlinie 2007/60/EG des Europäischen Parlamentes und des Rates vom 23. Oktober 2007 über die Bewertung und das Management von Hochwasserrisiken, Amtsblatt der Europäischen Union, L 288, 27-34, Brussels, 2007.

Glaser, R., Riemann, D. Schönbein, J., Barriendos, M., Brázdil, R., Bertolin, C., Camuffo, D. Deutsch, M., Dobrovolný, P., van Engelen, A., Enzi, S., Halíčková, M., Koenig, S. J., Kotyza, O., Limanówka, D., Macková, J., Sghedoni, M., Martin, B., and Himmelsbach, I.: The variability of European floods since AD 1500, Clim. Change, 101, 235-256, 2010.

Hahn, H.-U.: Die morphogenetische Wirksamkeit historischer Niederschläge, Würzburger Geographische Arbeiten, 82, 1-196, Würzburg, 1992.

Herget, J.: Am Anfang war die Sintflut - Hochwasserkatastrophen in der Geschichte, Primus, Darmstadt, 2012.

Herget, J. and Meurs, H.: Reconstructing peak discharges for historic flood levels in the city of Cologne - Germany, Global Planet Change, 70, 108-116, 2010.

Herget, J., Bremer, E., Coch, T., Dix, A., Eggenstein, G., and Ewald, K.: Engineering impact on river channels in the River Rhine catchment, Erdkunde, 59-3/4, 294-319, 2005.

Herget, J., Kapala, A., Krell, M., Rustemeier, E., Simmer, C., and Wyss, A.: Neues zur Magdalenenflut vom Juli 1342, Deutsche Wasserhistorische Gesellschaft Schriften, 22, 77-106, Siegburg, 2014.

House, P. K., Webb, R. H., Baker, V. R., and Levish, D. R. (Eds.): Ancient floods, modern hazards - principles and applications of paleoflood hydrology, American Geophysical Union, Washington, 2002.

Kidson, R. and Richards, K. S.: Flood frequency analysis - assumptions and alternatives, Prog. Phys. Geog., 29, 392-410, 2005.

Kiss, A.: Floods and weather in 1342 and 1343 in the Carpathian Basin, J. Environmental Geog., II, 37-47, 2009.

Macdonald, N., Werritty, A., Black, A. R., and McEwen, L. J.: Historical and pooled flood frequency analysis for the River Tay at Perth - Scotland, Area, 38, 34-46, 2006.

Meurs, H.: Bestimmung der Spitzenabflüsse historischer Hochwasser in Köln. Diploma thesis, Department of Geography, University of Bonn, 2006.

Morgenschweis, G.: Hydrometrie, Springer, Berlin, 2011.

Pang, K. D.: Extraordinary floods in early Chinese history and their absolute dates, J. Hydrol., 96, 139-155, 1987.

Qingchao, Y.: Fluvial processes of the lower Yellow River and estimation of flood conditions, in: Taming the Yellow River - silt and floods, edited by: Brush, L. M., Wolman, M. G., and Bing-Wei, H., Kluwer, Dordrecht, 261-274, 1989.

Roggenkamp, T. and Herget, J: Reconstructing peak discharges of historic floods of the River Ahr - Germany, Erdkunde, 68, 49-59, 2014.

Roggenkamp, T.: Rekonstruktion historischer Hochwasser der Ahr. Diploma thesis, Department of Geography, University of Bonn, 2012.

Savenije, H. G. G.: Recent extreme floods in Europe and the USA challenges for the future, Phys. Chem. Earth, 20, 433-437, 1995.

Schenk, W.: Auen als Siedlungs- und Wirtschaftsräume vor den ingenieurtechnischen Veränderungen des 19. Jhs. - das Mittelmaingebiet als Beispiel, Z. Geomorph. N.F. Suppl.-Bd., 124, 5567, 2001 
Schirmer, W.: Valley bottoms in the late Quaternary, Z.f. Geomorph. N.F. Suppl., 100, 27-51, 1995.

St. George, S. and Nielsen, E.: Flood ring evidence and its application to paleoflood hydrology of the Red River and Assiniboine River in Manitoba, Géogr Phys. Quatern., 56, 181-190, 2002.

Stoffel, M., Bollschweiler, M., Butler, D. R., and Luckman, B. H. (Eds.): Tree rings and natural hazards - a state of the art, Springer, Dortrecht, 2010.

Thorndycraft, V. R., Benito, G., Barriendos, M., and Llasat, M. C. (Eds.): Palaeofloods, historical data \& climatic variability - applications in flood risk assessment, Centro de Ciencias Medioambientales, Madrid, 2003.

Thorndycraft, V. R., Benito, G., Rico, M., Sopeña, A., Sánchez, Y., and Casas, M.: A long-term flood discharge record derived from slackwater flood deposits of the Llobregat River, NE Spain, J. Hydrol., 313, 16-31, 2005.
Weikinn, C.: Quellentexte zur Witterungsgeschichte Europas von der Zeitenwende bis zum Jahre 1850 - Band 1 - Zeitenwende bis 1500, Akademie, Berlin, 1958.

Wetter, O., Pfister, Ch., Weingartner, R., Luterbacher, J., Reist, T., and Trösch, J.: The largest floods in the High Rhine basin since 1268 assessed from documentary and instrumental evidence, Hydrol. Sci. J., 56, 733-758, 2011.

Witte, W., Krahe, P., and Liebscher, H.-J.: Rekonstruktion der Witterungsverhältnisse im Mittelrheingebiet von 1000 n.Chr. bis heute anhand historischer hydrologischer Ereignisse, Internationale Kommission für die Hydrologie des Rheingebietes KHR, Bericht II-9, Lelystad, 1995.

Zbinden, E.: Das Magdalenenhochwasser von 1342 - der hydrologische Gau in Mitteleuropa, Wasser Energie Luft, 103, 193-203, 2011. 